\title{
RESULTS OF THE RESEARCH OF USING THE MULTIMEDIA TEACHING AID UNDER REAL CONDITIONS AT PRIMARY SCHOOLS IN SVK
}

\section{Ján STEBILA}

\begin{abstract}
Introduction to creating and using the proposed multimedia teaching aid forms the basis of the dissertation thesis. Another focus is put on the empirical pedagogic research, a substantial part of which is the analysis of pedagogic documentation of the technical education teacher, description of the experiment and statistical analysis of the results. The objective of the research was to verify the successfulness of the use of the mentioned multimedia aid in the real conditions of an elementary school. It can be assumed that the multimedia aid proposed for the RSE will help to increase the efficiency of the technical education.
\end{abstract}

Key words: Technical education, Road safety education, Multimedia teaching aid, research, pupil, teacher, educational process.

\section{VÝSLEDKY Z VÝSKUMU POUŽITIA MULTIMEDIÁLNEJ UČEBNEJ POMÔCKY V REÁLNÝCH PODMIENKÁCH ZÁKLADNÝCH ŠKÔL V SR}

Resumé: Významnou súčastou článku je popis návrhu a použitia multimediálnej učebnej pomôcky. Ťažiskom d'alšieho záujmu bol empirický pedagogický výskum, ktorého súčastou je i realizácia pedagogického experimentu a štatistické spracovanie výsledkov výskumu s ciel'om prakticky overit' úspešnost' použitia učebnej pomôcky v reálnych podmienkach základnej školy. Predpokladá sa, že nami navrhnutá multimediálna učebná pomôcka pre dopravnú výchovu zvýši efektívnost' vyučovania v predmete Technická výchova.

Kl'účové slová - technická výchova, dopravná výchova, multimediálna učebná pomôcka, výskum, žiak, učitel', vyučovací proces.

\section{Úvod}

Kvalita dopravnej výchovy na Slovensku bola a stále je doposial' zabezpečovaná na individuálnej úrovni. Nadpredmetové učebné osnovy pre DV sú v platnosti, čoskoro sa vypracujú aj jednotlivé učebnice pre dopravnú výchovu. Rozdiel medzi formálnym a skutočným vzdelávaním je príliš často závislý od jednotlivých vyučujúcich a ich metód.

Téma článku vznikla v snahe zamerat' sa na špecifiká vo vyučovacom procese danej problematiky. Považujeme za dôležité, vzhl'adom na neuspokojivý stav učebných pomôcok, skúmat' problematiku dopravnej výchovy a zavádzanie nových učebných pomôcok do vyučovacieho procesu. Pozornost' sme prirodzene obrátili na vytvorenie a uplatnenie multimediálnej učebnej pomôcky vo vyučovacom procese, ktorú sme následne overovali prostredníctvom pedagogického experimentu. Predpokladá sa, že nami navrhnutá multimediálna učebná pomôcka pre dopravnú výchovu zvýši efektívnost' vyučovania.

\section{Súčasný stav problematiky}

Vstupom Slovenska do Európskej únie sme museli pristúpit' k určitým zmenám, ktoré vyplývali z povinností každého člena. Európska komisia vyhlásila voblasti znižovania nehodovosti na cestách Európsku chartu bezpečnosti cestnej premávky. Jej ciel'om je znížit' nehodovost' so smrtel'nými následkami na cestách Európy do roku 2010 o $50 \%$, a to konkrétnymi postupmi a metódami, pričom za východiskový sa považuje rok 2002. To znamená, že do roku 2010 by sa malo v Európe zachránit' 20000 l'udských životov.

Vláda Slovenskej republiky na svojom 132 rokovaní, ktoré sa uskutočnilo dňa 18. 5. 2005, schválila Národný plán na zvyšovanie bezpečnosti cestnej premávky na II. polrok 2005 s výhl'adom do roku 2010, v ktorom sú rozpracované opatrenia na plnenie ciel'ov charty.

Rada vlády Slovenskej republiky pre bezpečnost' cestnej premávky prerokovala na svojom druhom zasadaní materiál s názvom 
Informácia o realizácii dopravnej výchovy žiakov na detských dopravných ihriskách. Skonštatovala, že stav detských dopravných ihrísk a výučby dopravnej výchovy je horší ako sa predpokladalo a v tejto súvislosti uložila Ministrovi školstva Slovenskej republiky v spolupráci s Ministrom dopravy, pôšt a telekomunikácií SR pripravit' návrh koncepcie vyučovania dopravnej výchovy a koncepcie rozvoja detských dopravných ihrísk, vrátane možností ich aktivácie s ohl'adom na Národný plán.

Ministerstvo školstva SR poverilo Štátny pedagogický ústav SR vypracovat' Koncepciu vyučovania dopravnej výchovy na základných školách v Slovenskej republike. Pri plnení jednotlivých úloh ministerstvo vychádzalo z Národného plánu, kde malo klúčové tri úlohy:

- vytvorit' primerané, obsahové, materiálne a personálne podmienky na zvyšovanie úrovne dopravnej výchovy na základných školách,

- vytvorit' podmienky pre praktický výcvik žiakov na DDI, aktivizovanie ich činností,

- priebežné realizovanie sút'aže $N a$ bicykli bezpečne.

Okrem Koncepcie výučby DV na základných školách v Slovenskej republike bola v roku 2005 Ministerstvom školstva SR vypracovaná a schválená (hlavný riešitel' Palkovič) aj Koncepcia rozvoja dopravných ihrísk vrátane možnosti ich aktivácie s ohl'adom na Národný plán na zvýšenie bezpečnosti cestnej premávky. Jednotlivé opatrenia sa postupne realizujú. Na ich základe sa pripravili a následne 1. septembra 2007 MŠ SR schválili Nadpredmetové učebné osnovy dopravnej výchovy pre 1. až 9. ročník ŽS , do ktorých boli zapracované nové ciele obsahu výchovy a vzdelávania v oblasti DV žiakov.

\section{Multimediálna učebná pomôcka pre dopravnú výchovu}

Ked’že náš dlhodobý záujem bol a stále je zarad'ovat' a učit' žiakov prvky DV voblasti predmetu Technická výchova, pričom nové inovačné prístupy umožňujú použitie multimédií a počítačov vo vyučovaní, snažili sme sa využit' svoje schopnosti, vedomosti i potenciál pri hladaní a samotnej tvorbe efektívnej, novej učebnej pomôcky, ktorá by $\mathrm{v}$ plnej miere nahradila momentálny deficit učebných pomôcok pre danú problematiku a v plnej miere zefektívnila vyučovanie.
Jadrom MUP sú špeciálne vytvorené prezentácie a učebný text uložený vo forme CD. MUP akceptuje súčasný stav voblasti informačných technológií a pedagogickopsychologických postupov. Pri samotnej tvorbe sme vychádzali zo svojich skúseností, zručností a vedomostí $\quad \mathrm{z}$ oblasti DV, tvorby multimediálnych programov, psychológie a didaktiky technických predmetov.

Učebná pomôcka prezentuje žiakom nové učivo, postupy a riešenia problémových úloh z oblasti DV. Spočiatku vyžaduje intenzívnu prácu s počítačom a je spojená s určitým rizikom, ktoré je pri používaní počítačov vo výučbe vždy prítomné. Výučba prostredníctvom MUP prináša učitelovi i samotným žiakom omnoho viac radosti z učenia tejto problematiky a efektívnost' vzdelávacieho procesu viacnásobne prevyšuje tradičné metódy vyučovania. MUP pomáha žiakom dosiahnut' samostatnost', motivuje ich k aktívnemu učeniu, učí ich hl'adat' a využívat' informácie, potrebné pre ich samostatný pohyb v cestnej premávke. Podporuje aktivitu i zodpovednost'. Žiaci sa prostredníctvom MUP naučia objavovat', riešit' problémy, experimentovat' a klást' otázky $\mathrm{k}$ danej problematike.

Učitel pri jej používaní počas vyučovania vystupuje $\mathrm{v}$ úlohe poradcu i organizátora. Vyberá učivo založené na potrebách a záujmoch žiakov. Podporuje otvorenú komunikáciu, riešenie, myslenie, nápady a vedie žiakov $\mathrm{k}$ tomu, aby sami robili rozhodnutia. Vyžaduje od žiakov, aby hodnotili svoju činnost' a vyjadrovali svoje názory.

Ak sa žiaci učia akýmkol'vek praktickým alebo intelektuálnym schopnostiam, majú určité potreby. Objavujú sa, ked' sa žiaci učia to, čo vyžaduje korigovanú prax.

Pri tvorbe MUP sme sa snažili spojit' výhody tradičnej a alternatívnej školy. Učebná pomôcka, okrem kognitívnych potrieb žiaka, pomáha učitel'ovi z časti napíňat' aj afektívne potreby.

\section{Empirický, experimentálny výskum \\ 3.1 Predmet výskumu}

Predmetom výskumu boli žiaci 2. stupňa ZŠ, u ktorých sa vyučovanie v predmete Technická výchova vo vybraných tematických celkoch realizovalo nami navrhnutou MUP z oblasti dopravnej výchovy soptimálnou podporou informačných a komunikačných technológií. 
3.2 Ciele výskumu

Hlavným ciel'om výskumu bolo overenie úspešnosti použitia MUP $\mathrm{v}$ reálnych podmienkach vybraných škôl v predmete Technická výchova, kde sa využila aj práca s počítačom. Skúmali sme vedomosti na prvých troch úrovniach vzdelávacích ciel'ov Niemierkovej taxonómie a aktívne učenie sa žiakov.

$\mathrm{Na}$ splnenie ciel'a sme stanovili nasledovné čiastkové úlohy:

- Analýzou pedagogickej dokumentácie (učebných osnov, vzdelávacieho štandardu, učebnice, nadpredmetových učebných osnov pre DV) poukázat' na potrebu výučby dopravnej výchovy v predmete Technická výchova.

- Navrhnút' MUP, zameranú na rozvoj dopravnej výchovy žiakov 6 . ročníka v predmete Technická výchova na 2. stupni ZŚS.

- Pomocou výskumných techník a metód overit' stanovené hypotézy.

- Zistit', či uplatnenie MUP pre dopravnú výchovu ovplyvní úroveň teoretických vedomostí žiakov 6. ročníka základnej školy v predmete Technická výchova na ZŠ.

\subsection{Hypotézy výskumu}

$Z$ vyššie vysloveného ciel'a sme sformulovali nasledovnú hlavnú, východiskovú hypotézu:

H: Použitie nami navrhnutej multimediálnej učebnej pomôcky vo vyučovaní predmetu Technická výchova na 2. stupni ZŠ štatisticky významne ovplyvní úroveň vedomostí žiakov v oblasti dopravnej výchovy.

Aby sme mohli potvrdit' alebo vyvrátit' a jednoznačne verifikovat' hlavnú, východiskovú hypotézu, sformulovali sme nasledovné pracovné hypotézy:

H1: Pri riešení úloh didaktického testu, zameraného na oblast' dopravnej výchovy, dosiahnu žiaci v experimentálnej skupine štatisticky významne lepšie výsledky v prvých troch oblastiach Niemierkovej taxonómie ako žiaci v kontrolnej skupine.

H2: Žiaci vyučovaní pomocou MUP dosiahnu na konci experimentálneho vyučovania $\mathrm{v}$ didaktickom teste vyšší výkon v oblasti špecifického transferu ako žiaci vyučovaní tradične.

H3: Žiaci vyučovaní pomocou MUP dosiahnu na konci experimentálneho vyučovania $v$ didaktickom teste vyšší výkon voblasti zapamätania ako žiaci vyučovaní tradične.

H4: Žiaci vyučovaní pomocou MUP dosiahnu na konci experimentálneho vyučovania $\mathrm{v}$ didaktickom teste vyšší výkon voblasti porozumenia ako žiaci vyučovaní tradične.

H5: Žiaci v experimentálnej skupine, kde sa používa MUP, sa budú učit na hodinách aktívnejšie ako žiaci v kontrolnej skupine, kde sa táto MUP nepoužíva.

\subsection{Výskumné metódy a techniky}

$\mathrm{Z}$ titulu dosiahnutia stanovených ciel'ov a na overenie hypotéz boli navrhnuté nasledovné výskumné metódy a techniky empirického výskumu:

- literárna metóda, metóda obsahovej analýzy pedagogických dokumentov,

- prirodzený pedagogický experiment - hlavná metóda výskumu,

- didaktický test na overenie hypotéz (H1, H2, $\mathrm{H} 3, \mathrm{H} 4)$,

- štandardizovaný dotazník AUS (Rotling Sihelský, 2001) na overenie hypotézy (H5),

- štatistické metódy na spracovanie výsledkov výskumu.

\subsection{Identifikácia súboru respondentov}

Ciel'om úlohy bolo vhodne zvolit' experimentálnu a kontrolnú skupinu žiakov. Vzhl'adom $\mathrm{k}$ tomu, že sme chceli použit' na analýzu údajov štatistické metódy, ktoré predpokladajú určité (nie náhodné) premyslené zarad’ovanie žiakov do experimentálnych a kontrolných skupín, rozhodli sme sa výberový súbor zostavit' na základe porovnania vedomostnej úrovne žiakov. Pred začatím experimentu sme pomocou vstupného didaktického testu (pretest) zist'ovali, či je vedomostná úroveň žiakov kontrolnej a experimentálnej skupiny rovnaká.

Súbor respondentov predstavuje 214 žiakov, z toho 107 žiakov experimentálnej skupiny EXP i kontrolnej skupiny KON. 


\begin{tabular}{|l||c|c|}
\hline Názov školy & $\begin{array}{c}\text { kontrolná skupina } \\
\text { súbor 1 - KON }\end{array}$ & $\begin{array}{c}\text { experimentálna skupina } \\
\text { súbor 2 - EXP }\end{array}$ \\
\hline \hline Základná škola I (Poprad) & 22 & 22 \\
\hline Základná škola II (BB Sitnianska) & 24 & 24 \\
\hline Základná škola III (BB Spojová) & 25 & 25 \\
\hline Základná škola IV (Brezno) & 12 & 12 \\
\hline Základná škola V (Snina) & 24 & 24 \\
\hline \hline SPOLU $\sum$ & 107 & 107 \\
\hline
\end{tabular}

Tabul'ka 1: Počet respondentov zapojených do pedagogického výskumu

\section{Výsledky výskumu}

V tejto časti článku popisujeme, čo sme chceli zistit', prečo to bolo potrebné a ako sa získavali a spracovali jednotlivé informácie pedagogického experimentu. Pre názornost' a limitovaný počet strán uvádzame štatistické vyhodnotenie len prvej hypotézy.

\section{Pracovná hypotéza H1:}

Pri riešení úloh výstupného didaktického testu, zameraného na oblast' dopravnej výchovy, dosiahnu žiaci v experimentálnej skupine štatisticky významne lepšie výsledky ako žiaci v kontrolnej skupine.

$\mathrm{Na}$ verifikáciu tejto hypotézy sme použili výsledky výstupného didaktického testu. Skóre výstupného didaktického testu v oboch skupinách splńnalo podmienku normálneho rozdelenia. Štatistickú verifikáciu tejto hypotézy sme uskutočnili na hladine významnosti 0,05 dvojvýberovým T-testom a parametrickým F-testom.

Meranie výkonu žiakov z problematiky dopravnej výchovy v predmete Technická výchova sme realizovali výstupným didaktickým testom $\mathrm{v}$ každej podskupine experimentálnej a kontrolnej skupiny zvlášt'. Test s 18 otázkami realizovalo 214 žiakov. Výsledky tohto výstupného testu sme analyzovali metódami deskriptívnej štatistiky, ktorej výsledky a charakteristiky sú prehl'adne uvedené v nasledujúcej tabul'ke.

\begin{tabular}{|c|c|c|c|c|c|c|c|c|c|c|c|c|}
\hline 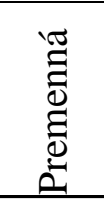 & 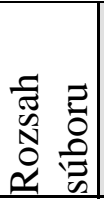 & 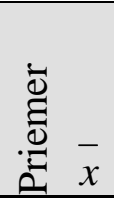 & 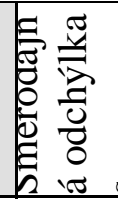 & 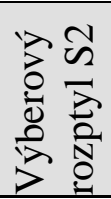 & $\frac{n}{\tilde{z}}$ & 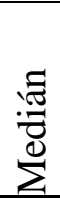 & 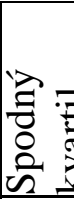 & 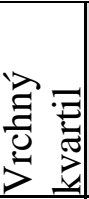 & $\stackrel{\Xi}{\Xi}$ & $\underset{\Xi}{\Xi}$ & 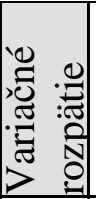 & $\begin{array}{c}\text { Interval } \\
\text { spol'ahlivosti pre } \\
\text { strednú hodnotu } \\
\alpha=0,05\end{array}$ \\
\hline EXP & 107 & 29,71 & 3,16 & 9,98 & 33 & 30 & 28 & 33 & 20 & 33 & 13 & $(29,11 ; 30,31)$ \\
\hline KON & 107 & 28,82 & 3,72 & 13,86 & 28 & 29 & 28 & 32 & 14 & 33 & 19 & $(28,02 ; 29,52)$ \\
\hline
\end{tabular}

Tabul'ka 2: Popisná štatistika súboru dát analyzovaných v súvislosti s hypotézou HI

Prvým výstupom zo spracovania zozbieraných údajov je tabul'ka 2, ktorá obsahuje základné popisné štatistiky súboru dát, t. j. aritmetický priemer, medián, modus, variačné rozpätie a kvartily. Sú v nej aj výpočty mier rozptýlenia okolo strednej hodnoty (výberový rozptyl, smerodajná odchýlka, štandardná chyba aritmetického priemeru) a interval spol'ahlivosti pre strednú hodnotu (na hladine významnosti $\alpha=0,05$ ).

Zo zostavených frekvenčných tabuliek a následne vytvoreného histogramu porovnávajúceho s krivkou normálneho rozdelenia je zrejmé, že uvedené dáta nie sú normálne rozdelené.
Graf 1 znázorňuje histogram premennej VYK v experimentálnej a kontrolnej skupine, preložený ideálnou krivkou (hustota) normálneho rozdelenia (tzv. Gaussova krivka). Dáta s týmto rozdelením sa nazývajú normálne rozdelené dáta. $Z$ histogramov možno povedat', že početnosti vel'mi málo aproximujú normálnemu rozdeleniu. Zároveň je z grafu vidiet', že priemery sú od seba vzdialené.

$Z$ výsledkov konštatujeme, že žiaci dosiahli $\mathrm{v}$ didaktickom teste rozdielne skóre a na jednotnej stupnici sa umiestnili v rôznych kvalitatívnych intervaloch.

Najvyššie skóre didaktického testu dosiahol žiak v experimentálnej aj kontrolnej skupine (33 bodov). 

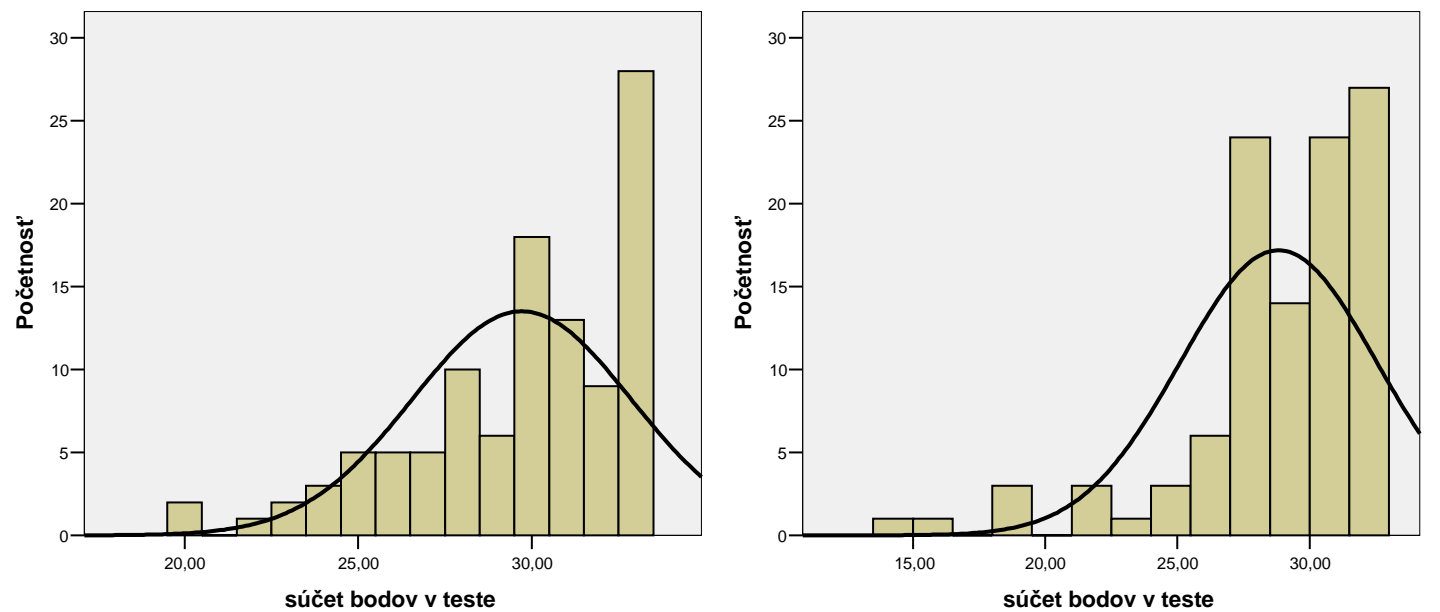

Graf 1: Histogram početností premennej VYK v experimentálnej a kontrolnej skupine

Najnižšie skóre v didaktickom teste dosiahol len žiak $\mathrm{z}$ kontrolnej skupiny (14 bodov). Aritmetické priemery obidvoch skupín vypovedajú o tom, že žiaci v experimentálnej skupine $\mathrm{v}$ priemere o menej ako 1 bod prekonali žiakov z kontrolnej skupiny. Porovnaním smerodajných odchýlok konštatujeme, že homogénnost' obidvoch skupín je porovnatel'ná, teda MUP výrazne nezvyšuje ani neznižuje rozptyl hodnôt skóre jednotlivých žiakov.

Pri riešení úloh výstupného didaktického testu, zameraného na oblast' dopravnej výchovy, dosiahli žiaci v experimentálnej skupine štatisticky významne lepšie výsledky ako žiaci v kontrolnej skupine. Toto tvrdenie platí s pravdepodobnost'ou $95 \%$ a vzt'ahuje sa na všetkých respondentov základného súboru.

\section{Hypotéza $\mathrm{H1}$ sa potvrdila.}

\section{Zhrnutie výsledkov výskumu}

Platnost' pracovných hypotéz na hladine významnosti 0,05 je zhrnutá v nasledujúcej tabul'ke:

\begin{tabular}{|c|c|c|c||}
\hline Hypotéza & Metóda získavania faktov & Platnost' hypotézy & Skúmaná veličina \\
\hline \hline H1 & DT - výstupný & platí & Výkon v kognit. oblasti \\
\hline H2 & DT - výstupný & platí & Uplatnenie \\
\hline H3 & DT - výstupný & platí & Zapamätanie \\
\hline H4 & DT - výstupný & platí & Porozumenie \\
\hline H5 & Štandard. dotazník AUS & platí & Aktívne učenie \\
\hline
\end{tabular}

Tabul'ka 3: Sumarizácia verifikácie jednotlivých hypotéz

Zo štatistických analýz a záverov testovania parciálnych hypotéz je možné konštatovat', že na zvolenej hladine významnosti 0,05 a pri daných podmienkach je východisková hypotéza potvrdená a pravdivá. Výskumom aplikácie prezentovanej MUP a jej metodiky na hladine významnosti 0,05 môžeme konštatovat', že:

- Žiaci vyučovaní pomocou MUP dosiahli na konci experimentálneho vyučovania v didaktickom teste vyšší výkon v oblasti špecifického transferu, porozumenia a zapamätania ako žiaci vyučovaní tradične.
- Žiaci vyučovaní pomocou MUP sa na hodinách učili aktívnejšie ako žiaci vyučovaní tradične.

\section{Odporúčania pre pedagogickú teóriu a prax}

6.1 Závery a odporúčania pre pedagogickú teóriu

1. Informovat' a poukázat' MŠ $S R$ a ŠPU (sekciu pre dopravnú výchovu), na miesta, ktoré je potrebné dopracovat' a zmenit' v súčasných nad-predmetových učebných osnovách pre DV. 
2. Publikovaním výsledkov výskumu v odborných časopisoch a zborníkoch oboznámit' odbornú verejnost' s možnost'ou rozvoja dopravnej výchovy žiakov, a tým prispiet' k spolupráci učitel'ov na riešení danej problematiky.

3. Dostupnými formami informovat' pracovníkov Štátneho pedagogického ústavu SR a v ňom pôsobiace komisie o súčasnom stave a vedomostnej úrovni žiakov z oblasti problematiky dopravnej výchovy s ciel'om zlepšenia v praxi.

\subsection{Závery a odporúčania pre pedagogickú prax}

1. Inovovat' obsah vzdelávania v predmete Technická výchova v prospech implementácie IKT do edukačného procesu.

2. Vytvorit' učebnice pre DV na všetkých stupňoch vzdelávania.

3. Vytvorit' systém vzdelávania DV v pregraduálnej príprave. Priestor na túto prípravu vidíme $\mathrm{v}$ príprave učitel'ov technickej výchovy.

4. Vytvorit' systém celoživotného vzdelávania učitel'ov zodpovedných za realizovanie DV na školách.

\section{Záver}

Teoretickú čast' pedagogického výskumu sme zamerali na analýzu súčasného stavu problematiky dopravnej výchovy na Slovensku i v zahraničí. Identifikovali sme potrebu zmeny obsahu vzdelávania a tvorby nových učebných pomôcok. Súčast'ou je aj podrobne spracovaná metodika a odporúčania použitia MUP.

Výskumnú čast' sme sústredili na empirické overenie piatich pracovných hypotéz. Pri overovaní ich platností sme využili pedagogický experiment, didaktické testy, dotazníkovú metódu a štatistické metódy spracovania výsledkov výskumu.

Výsledky realizovaného experimentu ukazujú, že použitie MUP v predmete Technická výchova prispieva k vyššej efektívnosti v oblasti zapamätania, porozumenia, špecifického transferu a aktívneho učenia sa žiakov. Stanovené hypotézy sa potvrdili.

Je nevyhnutné, aby učitelia svoje prípravy, metódy a učebné pomôcky pravidelne aktualizovali, doplńali. Mali by pri svojej práci využívat' všetky dostupné materiálno-technické prostriedky, vedomosti z oblasti pedagogiky, psychológie, didaktiky, ktoré môžu zatraktívnit' vyučovací proces.

\section{Zoznam použitej literatúry}

(1) PALKOVIČ. J. Koncepcia vyučovania dopravnej výchovy na základných školách v SR. Bratislava: MS̆ SR, 2006.

(2) PALKOVIČ. J. Koncepcia rozvoja detských dopravných ihrísk. Bratislava: MŠ SR, 2005.

(3) LADÁNYI, J., ALFÖLDYOVÁ, I. Nadpredmetové učebné osnovy DV pre 1. až 9. ročník. MŠ SR, 2007. s. 2.

(4) ROAD SAFETY IS NO ACCIDENT. A brochure for World Day 7 april 2004. Geneva: World Health Organisation, 2004.

(5) KOŽUCHOVÁ, M.: Inovačné zmeny v dopravnej výchove. In: Technické vzdelávanie $\mathrm{v}$ procese zmien. Banská Bystrica: FPV UMB, 2007, s. 59-64, ISBN 97880-8083-5309.

(6) KOŽUCHOVÁ, M., STEBILA, J. (ed.). Ako rozvíjat' dopravnú gramotnost' detí. CD. Bratislava: UK, 2007. 85 s. ISBN 978-80-2232363-5.

(7) STEBILA, J.: Zaradenie dopravnej výchovy do obsahu vyučovania predmetu Technická výchova na 2. stupni základnej školy. (Dizertačná práca), Banská Bystrica: KTT FPV UMB, 2008.

(8) STEBILA, J. Multimediálna učebná pomôcka pre dopravnú výchovu na ZŠ. In: Trendy technického vzdelávaní, Olomouc: 2004, 128s. ISBN 80-7220-182-4.

(9) STOJAN, M. a kol. Dopravní výchova pro učitele 1. stupne ZŠ. Brno: PF MU, 2007. ISBN 978-80-210-4251-3.

(10) Traffic Safety Education at the Secondary School Level in the EU Countries. Europen Study. Brussels: European Road Safety Federation ERSF, 1996.

(11) VOTRUBA, J. Dopravní výchova v rodině. Praha: BESIP - Fortuna, 2001.

Ján Stebila., PaedDr., PhD.

Katedra techniky a technológií, FPV UMB BB

Tajovského 40, 97401, Banská Bystrica, telefón 048/446 7217, e-mail: stebila@fpv.umb.sk 